\title{
London: A Multi-Century Struggle for Sustainable Development in an Urban Environment
}

\section{Citation}

Clark, William C. 2015. London: A Multi-Century Struggle for Sustainable Development in an Urban Environment. HKS Faculty Research Working Paper Series RWP15-047.John F. Kennedy School of Government, Harvard University.

\section{Permanent link}

http://nrs.harvard.edu/urn-3:HUL.InstRepos:22356529

\section{Terms of Use}

This article was downloaded from Harvard University's DASH repository, and is made available under the terms and conditions applicable to Other Posted Material, as set forth at http:// nrs.harvard.edu/urn-3:HUL.InstRepos:dash.current.terms-of-use\#LAA

\section{Share Your Story}

The Harvard community has made this article openly available.

Please share how this access benefits you. Submit a story. 


\section{London: A Multi-Century} Struggle for Sustainable Development in an Urban Environment

\section{Faculty Research Working Paper Series}

\section{William C. Clark}

Harvard Kennedy School

\section{August 2015 \\ RWP15-047}

Visit the HKS Faculty Research Working Paper Series at:

https://research.hks.harvard.edu/publications/workingpapers/Index.aspx

The views expressed in the HKS Faculty Research Working Paper Series are those of the author(s) and do not necessarily reflect those of the John F. Kennedy School of Government or of Harvard University. Faculty Research Working Papers have not undergone formal review and approval. Such papers are included in this series to elicit feedback and to encourage debate on important public policy challenges. Copyright belongs to the author(s). Papers may be downloaded for personal use only. 


\title{
"London: A multi-century struggle for sustainable development in an urban environment"
}

\author{
William C. Clark ${ }^{*}$ \\ Forthcoming in modified form in Pamela Matson, William C. Clark and Krister Andersson, \\ Pursuing Sustainability: A Guide to the Science and Practice. Princeton Univ. Press 2016.
}

\begin{abstract}
In this paper I sketch key episodes in the two thousand year history of interactions between society and environment that have shaped the City of London and its hinterlands. My purpose in writing it has been to provide an empirical puzzle for use in teaching and theorizing about the long term coevolution of social-environmental systems and the potential role of policy interventions in guiding that coevolution toward sustainability. I undertook it because while a lively body of theory has begun to emerge seeking to explain such coevolution, rich descriptive characterizations of how specific social-environmental systems have in fact changed over the long time periods (multi-decade to multi-century) relevant to sustainable development remain relatively rare. One result is that the field of sustainability science lacks a sufficient number of the rich empirical puzzles that any field of science needs to challenge its theorizing, modeling and predictions. This paper reflects the beginning of an effort to provide one such characterization on a topic central to sustainability: the long term development of cities and their hinterlands.
\end{abstract}

\footnotetext{
"William C. Clark (william clark@harvard.edu) is Harvey Brooks Professor of International Science, Public Policy and Human Development at Harvard's Kennedy School of Government and serves as the co-director of the Sustainability Science Program at Harvard University. The author thanks Graham Clark for research assistance. The text has benefited from suggestions and comments by Krister Andersson, Anna Clark, Graham Clark, Adam Clark, Pamela Matson, Kira Matus and Nora O'Neil. Support from Italy's Ministry for Environment, Land and Sea is gratefully acknowledged.

+C 2015 by William C. Clark. All rights reserved. Short sections of text, not to exceed two paragraphs, may be quoted without explicit permission provided that full credit, including $@$ notice, is given to the source.
} 


\section{"London: A multi-century struggle for sustainable development in an urban environment"}

\section{Contents}

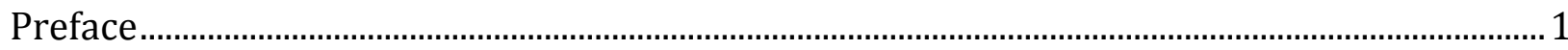

London: The struggle for sustainable development in an urban environment.......................... 3

Aspiring to Sustainability: London today ……............................................................................ 3

A Place by the Sea: London's founding to the Norman Conquest............................................... 4

Forest, Food and Fuel to the Plague of 1348: London in the Middle Ages .............................. 5

Muddling through to the Great Fire of 1666: London of the Tudors \& Stuarts ...................... 8

A Waste of Life: London's battle with disease in the 18th Century ............................................ 9

Water, Waste \& Sewers up to the Great Stink of 1858: Victorian London............................. 12

Persistent Air Pollution \& the Great Smog: London's 20th Century ...................................... 16

Sustainable development questions arising from the London case............................................ 18

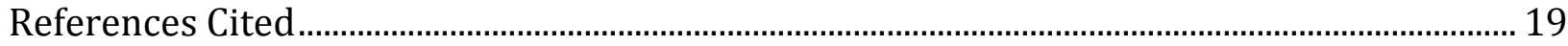

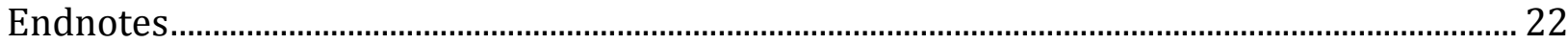

\section{Preface}

I wrote this paper as a case history for use in teaching about, and stimulating research on, the long term coevolution of social and environmental systems and the potential of policy interventions to guide that coevolution toward sustainability. In writing the case I found that I needed to draw on scholarship from history, demography, epidemiology and urban studies - all fields in which I have little or no formal training. Furthermore, I needed to integrate that scholarship into a coherent account of social-environmental interactions in the City of London-an extraordinarily complex place with which I have limited direct experience. The result is an incomplete work in progress. I would therefore be most grateful for corrections, suggestions of additional sources or perspectives, and more generally help for in producing a more accurate and useful case study. As background to this plea for help, a few words are perhaps in order on the niche that I am hoping that this study will ultimately help to fill.

The study of complex social-environmental (also called human-ecological) systems and the mutual impacts of their components on one another has a long heritage but has really taken off over the last couple of decades. It is now generally accepted, however, that the 
environment shapes society, that society in term shapes the environment and that interactions between the two systems must be often studied to make sense of either. This is especially true when one is trying to explain their dynamics over periods of decades to centuries. The practical importance of understanding such long term dynamics of socialenvironmental systems has been heightened by practical concerns about their sustainable development, what threatens it and what can be done to enhance it.

Over the last decade a lively body of theory has begun to emerge seeking to explain the dynamics of such complex adaptive social-environmental systems and the conditions for their sustainable development. ${ }^{1}$ Surprisingly, however, rich descriptive characterizations of how specific social-environmental systems have in fact changed over the long time periods (multi-decade to multi-century) relevant to sustainable development remain relatively rare. ${ }^{2}$ One result is that the field of sustainability science lacks a sufficient number of the rich empirical puzzles that any field of science needs to challenge its theorizing, modeling and predictions. It's as though we were stuck in the bad old days of trying to build theory about long term climate change without access to the Vostok ice cores, or about causes of the demographic transition without comparative national data on population sizes across space and time.

The majority of the long term characterizations of social-environmental dynamics of which I am aware tend to cover only particular episodes out of longer histories of interaction, and to focus disproportionately on relatively spectacular instances of apparent collapse or triumph rather than the more mundane but perhaps more common cases that involve elements of both. We can learn much from trying to understand such episodes. But they do not challenge us with the full variety of dynamics exhibited by social-environmental systems over the long run and thus are not sufficient as a challenge to or check on our theorizing about sustainable development. For that, we need more longer term characterizations of the full range of dynamics exhibited by complex, adaptive socialenvironmental systems. This paper reflects the beginning of an effort to provide one such characterization on a topic central to sustainability: the long term development of cities and their hinterlands.

William C. Clark Professor of International Science, Policy and Human Development John F. Kennedy School of Government Harvard University July 2015 


\section{London: The struggle for sustainable development in an urban environment}

Cities constitute increasingly important sites for understanding and managing the coevolution of society and environment. More than half of the world's people already live in cities, up from 14\% in 1900 and only 3\% in $1800 .{ }^{3}$ This urbanization trend seems inexorable: within the lifetimes of today's young adults, more than $2 / 3$ of the world's people are likely to be urbanites. ${ }^{4}$

Whether continuing urbanization will promote or imperil sustainable development has long been a subject of debate. On the one hand, as noted by the UN Population Fund:

Cities offer a more favorable setting for the resolution of social and environmental problems than rural areas. Cities generate jobs and income. With good governance, they can deliver education, health care and other services more efficiently than less densely settled areas simply because of their advantages of scale and proximity. Cities also present opportunities for social mobilization and women's empowerment. And the density of urban life can relieve pressure on natural habitats and areas of biodiversity. ${ }^{5}$

On the other, cities throughout history have been the settings for human squalor and indignity of unimaginable proportions. And urbanization has managed to degrade beyond livability both the immediate environments of cities and the environments of the hinterlands from which cities have drawn their resources and to which they have exported their wastes.

Most cities have experienced both of these faces of urbanization, whether through their histories, across their contemporary neighborhoods or both. It is therefore hard to disagree with the UN Secretary General's conclusion that "Our struggle for global sustainability will be won or lost in cities" of the world. ${ }^{6}$ For a look at that struggle, I examine in this paper the coevolution of society and environment in one of the world's great cities: London, England.

\section{Aspiring to Sustainability: London today}

London today is widely recognized as a leading "World City." It regularly scores at or near the top of surveys about sustainability and quality of life in urban areas, racking up especially high scores for its international clout, its technological savvy and its livability; doing well on economy, governance and many dimensions of environment, but still struggling with air pollution, housing and social cohesion. ${ }^{7}$ The City is proud of its position, relatively self-critical of its shortcomings and committed to doing better. A recent official plan for Greater London-an evolving document launched in the early years of the $21^{\text {st }}$ Century-centers on a 
Vision for the sustainable development of London... over the years to 2031 and beyond [in which] London should: excel among global cities-expanding opportunities for all its people and enterprises, achieving the highest environmental standards and quality of life and leading the world in its approach to tackling the urban challenges of the $21^{\text {st }}$ century, particularly that of climate change. ${ }^{8}$

That London can now aspire to such an ambitious vision for its future is remarkable-and instructive-when one considers the city's history. This consists of nearly two thousand years of apparently unsustainable developments, some very like those being experienced in today's most rapidly growing "new" cities. Over this period, a combination of ignorance and the pursuit of short term personal gains by Londoners repeatedly imposed long term, large scale costs of social and environmental degradation that eventually became untenable. But people responded with a mix of political activism, scientific discoveries, technological inventions, social adjustments and new forms of governance that-together with events occurring in the wider world beyond London-opened the way for the next round of development initiatives. These invariably led to their own surprises and readjustments of which the current plan for Greater London is but the latest installment.

How should we view the resulting whip-lash trajectory of London's historical development from the perspective of "sustainability?" What are the most important unanswered research puzzles posed by that trajectory? What should we learn from London's history that can help to guide the ongoing global process of urbanization on a path toward sustainable development? Posing such questions, and inviting exploration of potential answers to them, is the purpose of this paper.

\section{A Place by the Sea: London's founding to the Norman Conquest}

The Romans established the fortifications reflected in contemporary London's "square mile" around AD 50. The site they chose was, following the doctrines of Caesar's engineer Vetruvius, on a gentle slope well positioned for the sun to clear away mists and vapors from the lower grounds lying to the south. ${ }^{9}$ Like most places that eventually become major cities, London was also founded on a river-a source of water, food, power and transport. Its siting on the Thames River was special, however, placing London at the limits of where ocean tides affected the river's height and could thus also be used to help move goods up river from the open sea (about $80 \mathrm{~km}$ to the west) as well as seaward with normal river flow. This "two-directional" river setting helped to establish London as a major trading center. But it also meant that the city, along with much of its downstream hinterland, was vulnerable to flooding when strong North Sea storm surges coincided with exceptionally high tides. Efforts to build embankments and other protective works began in the earliest Roman times, continued through the medieval period, and included construction of the massive Thames Barrier gates in response to the flooding of the city in 1953. Efforts to retain the benefits of its place by the sea, while reducing the related vulnerabilities, are playing a central role in the city's plans for dealing with climate change in the $21^{\text {st }}$ Century. 
For its first thousand years of existence, London was repeatedly sacked, burned, occupied and abandoned. By the time of the Norman Conquest in 1066, however, it had become a substantial city with enduring structures (e.g., the Tower of London), its own governing charter, and a population of 10,000 or more. The needs of that population were, at first, readily provided by the natural environment of the city and its immediate hinterlands. Water was abundant and clean. The city was surrounded by rich marshlands and agricultural clearings that provided not only food but also a repository for human waste that was collected in the city and sold to the farmers as fertilizer. Beyond these intensively managed lands were extensive forests that furnished food, fuel and timber for construction. Reflecting the central importance of these forest lands to social life, an elaborate though not particularly equitable system of traditions, rights and laws emerged to govern who had access to them for what sorts of uses. ${ }^{10}$

\section{Forest, Food and Fuel to the Plague of 1348: London in the Middle Ages11}

The early medieval period was a time of rapid population growth in England as a whole, as well as in London which had become the country's principal city. From 1100 to 1300, the population quadrupled, reaching a peak of perhaps 80,000 inhabitants (see Figure 1). The challenges of providing for the city's increasing material and energy needs, and of disposing of the resulting wastes, increased accordingly.

Figure 1. London's population over the last millennium (thousands of people, log scale) ${ }^{12}$

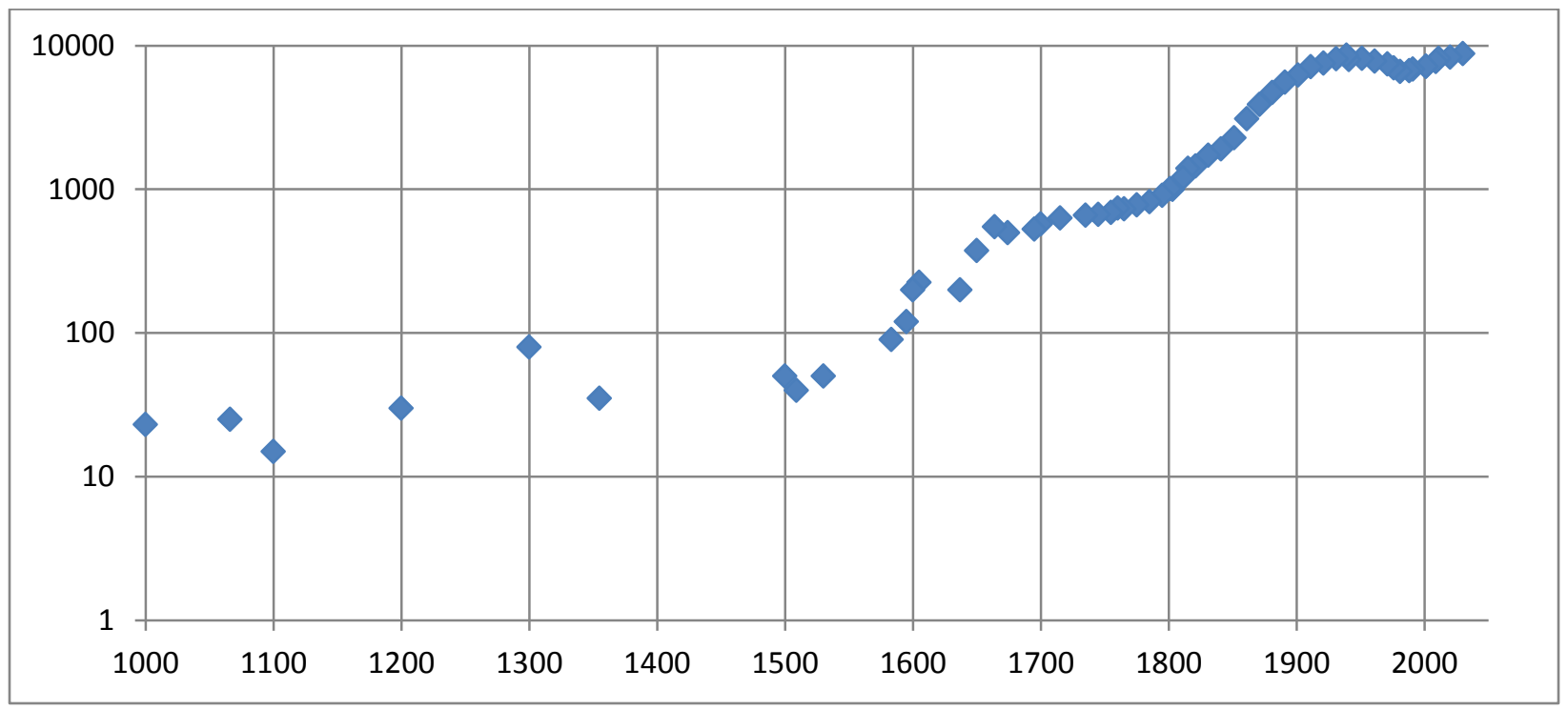

Some of the tightest early constraints on London's development involved water, both bringing it into the city and disposing of excess rainfall. To deal with the supply problem, numerous conduits were constructed to tap nearby ponds and lakes, as well as tributaries to the Thames, and to bring them all into the city center. Drainage was accomplished through unorganized runoff into the Thames and its tributaries, supplemented by the construction of additional "sewers" (modeled on those of Roman times) to capture runoff 
and convey it to the river. Industrial wastes, principally from breweries, tanneries, and the like, were dumped directly into the watercourses. Household waste, principally human excrement, was collected and disposed of in local cesspits (also called "cesspools" or "necessary chambers") that-as in earlier times-were periodically emptied and the contents (fittingly called "night soil") transported to the countryside for use as fertilizer.

This waste disposal system worked, after a fashion. But it wasn't perfect. Because the flow of water down the streets or through the sewers to the Thames was irregular and could be interrupted, industrial wastes sometimes built up and rotted in the midst of the city. Pig styes were early banned from the streets because of their contribution to these disposal problems and household cesspits were prohibited from connecting directly with the sewers. Overflows, however, were not uncommon. By 1189, regulations required that cesspits be located a minimum distance from property lines. Periodic complaints nonetheless occurred, as when the Carmelite Friars in 1290 felt obliged to petition that the "great stench" from the surrounding area made it impossible for them to carry out their religious duties. The problems became serious enough that by the mid-14th Century, successive Kings of England were moved to intervene. Edward III was particularly direct when he addressed the officials of London in 1357:

Whereas now, when passing along the water of the Thames, we have beheld dung and other filth accumulated in diverse places in the said City upon the bank of the river aforesaid and also perceived the fumes and other abominable stenches arriving therefrom... [we] do command you that you cause as well the banks of the said river, as the streets and lanes of the same City, and the suburbs thereof, to be cleaned of dung and other filth without delay and the same when cleaned to be so kept.13

The commands, however, do not seem to have been backed up by the knowledge of how to accomplish the job, the resources to do it or the governance structures to induce compliance. The stench would persist as an integral part of the London experience for another five centuries.

London's other great material need was for food. Some was supplied by the Thames fisheries, but most was imported from farmers working a network extending $65-100 \mathrm{~km}$ into the surrounding hinterlands. Increasing demand was met there through a combination of measures to increase yields on existing lands (e.g., through use of fertilizers, improved seeds, better management), plus efforts to expand the amount of land under cultivation. Together, these two supply responses managed to prevent serious hunger in much of Europe, including England and London, through the first half of the $13^{\text {th }}$ Century. ${ }^{14}$ By the beginning of the $14^{\text {th }}$ Century, however, agricultural expansion had been pushed to the limit. Food shortages and malnutrition became increasingly chronic conditions. Moreover, the massive forest clearing needed to increase the land available for agriculture had also decreased the amount available for timber production. In the area surrounding London, there was little forest land left except that reserved by the aristocracy for recreation and game reserves. The resulting scarcity of accessible wood and other forest products had a number of impacts on social life. These ranged from suffering among 
peasants who could no longer use the forest as their traditional subsistence backup when crops failed, to concern among royalty who could no longer find the timber needed for their building projects. Perhaps more surprisingly, the growing scarcity of wood also brought on what may have been the first of London's many air pollution crises.

Since London's founding, relatively clean-burning wood had been its primary source of fuel for providing heat to homes and manufacturing (e.g., for smelting, metal working and the production of lime for use in agriculture and building). But as forests made way for agricultural fields, wood and the charcoal made from it became increasingly scarce, distant and expensive. At the same time "sea coal" — a low-grade, soft, high-sulfur fossil fuel initially sourced from coastal deposits-was becoming cheap and available. By the late $13^{\text {th }}$ Century, wide-spread adoption of this new energy source in London was causing many complaints about "infected and corrupted air." In 1307 King Edward I intervened, prohibiting the use of sea coals in lime kilns because of the "intolerable smell" that resulted in "annoyance ... and injury of their bodily health" for all in the vicinity. "Grievous ransoms" were authorized to punish offenders. ${ }^{15}$ Complaints about fumes did subsequently decline, presumably reflecting improvement in air quality. In any case, air pollution did not again figure prominently in the documentation of London's affairs until well into the $16^{\text {th }}$ Century. It is tempting to attribute these apparent improvements in air quality to the effectiveness of informed government action. But Edward's royal decree coincided with the end of the medieval boom period. The declining demand for coal almost certainly helped to achieve the king's goal.

Other problems, however, were on the rise. Despite the expansion of agricultural land that had so dramatically reduced forest cover, in the early decades of the $14^{\text {th }}$ Century England-and indeed much of Europe-was struggling to feed itself. Food shortages, malnutrition and even starvation became the norm. Population and economic growth slowed.

Stagnation turned to collapse when the Black Death (almost certainly caused by the bubonic plague) reached London in 1348 after rapidly spreading through Europe from Asia. ${ }^{16}$ Within 18 months, an astonishing half of London's population was dead. The plague returned sporadically throughout the remainder of the century, reducing England's population overall by perhaps $40 \%$. (The plague would remain a significant cause of death in London for the next three hundred years.) The impacts of the Black Death on social wellbeing in the $14^{\text {th }}$ Century are incalculable. But just as the earlier increase in human numbers and activity had reshaped wetland and forest landscapes into agricultural ones, so the human depredations of the plague reversed that process. Untended embankments collapsed, letting the Thames reclaim much of its former broad flood-plain (and in the process reduce the vulnerability of up-stream London to storm-surges). ${ }^{17}$ Forests invaded the untended fields of London's hinterlands, soon providing enough wood to meet the much reduced demand of the much reduced London population. The use of sea coalwidely seen as less desirable than wood-declined accordingly. Complaints about air pollution declined with it. ${ }^{18}$ 


\section{Muddling through to the Great Fire of 1666: London of the Tudors \& Stuarts}

London did not recover its pre-plague population until the late $15^{\text {th }}$ Century. But by 1520 the city was again booming and, toward the middle of the century, came to occupy a central position in the growing world trade network. By the end of the reign of Elizabeth I in the early $17^{\text {th }}$ Century, London had become the preeminent population center of England, with perhaps 220,000 inhabitants. Immigration rates were substantial, as more and more people from England and abroad came to the city to take advantage of its economic, political and cultural attractions. Technical innovations abounded, including a water wheel that would pump water from the Thames to distribution points in the city for the next 240 years. The first private coaches also appeared, both speeding movement of people within the existing city and increasing its effective scale. Governance innovations were also advanced. A Bill of Sewers, meant to provide for systematic cleaning and drainage of the city, was introduced in $1531 .{ }^{19}$ Later efforts, reflecting awareness that the city was outgrowing its ability to function, sought to limit both the expansion of London's boundaries and the subdivision of its existing housing stock into ever smaller, more densely packed units. These efforts almost certainly had some impact. But they were wholly inadequate to the rapidly growing challenges of a rapidly growing city.

For example, as booming London once again pressed its surrounding forests to supply land for agriculture and timber for construction, wood again became too scarce or expensive for use as a heating fuel. Sea coal again became the dominant fuel source, again leading to complaints about foul emissions. This time, the king called on the newly emerging science establishment to assess the causes and consequences of troubling smokes. Those scientists got parts of the air pollution story about right by today's standards, concluding that smoke from coal burning industries caused material corrosion and damage to the lungs of city dwellers. And they advanced logical proposals for mitigating damage: pre-combustion treatment of coal to limit smoke emissions and movement of industries to the periphery of London. But there was no acute crisis to focus attention and no mechanism in place for the slow accumulation of knowledge to produce action. Science was ignored. London got smokier. ${ }^{20}$

The inadequacy of the system for solid waste disposal was also once again becoming apparent. The king wrote to London's mayor:

The king hath noticed that the ways in and about the City and liberties were very noisome and troublesome for passing, in consequences of breaches of the pavements and excessive quantities of filth lying in the streets. They require him, by the king's express command, to take effectual steps for the complete repair of the pavements and the removal of all filth... ${ }^{21}$

In short, the stinks of old were back. The king, as before, could command them to go away. But, as before, he was ultimately disappointed with the result of his orders. 
The combination of increasingly crowded living conditions, the build-up of human excrement in back yards, alleys and water supplies, and the growing trade with the rest of the world set the stage for an upsurge in infectious disease epidemics. ${ }^{22}$ These included not only the plague, which recurred at frequent intervals, but also an often undifferentiated and increasingly deadly mix of influenza, scarlet fever, tuberculosis, typhus, typhoid, diphtheria, measles, whooping cough and-above all-smallpox. As a result, it was not uncommon for London to lose $10 \%$ or more of its total population to epidemic disease outbreaks in any given decade. ${ }^{23}$ Then, in 1665, the "Great Plague" struck with a violence not seen since the first plague of the $14^{\text {th }}$ Century. With vastly more people, rats and fleas available in London to support the epidemic, the human toll was unprecedented: as many as 100,000 Londoners may have died over the seven months of the outbreak, with more than 7,000 per week perishing during its peak. Society at the time had no reliable understanding of the plague's causes, and therefore was left flailing about with a variety of largely ineffectual measures to combat it. These ranged from mass killings of dogs and cats (which presumably left the fleas that actually transmitted the disease looking for new hosts) to packing up and fleeing the city (which hastened the spread of the disease), to a breakdown of social networks as people refused to help sick servants, friends or family. Samuel Pepys glumly noted in his diary "the plague [is] making us cruel as dogs to one another." 24

Whether London's response to the Great Plague would have differed substantially from its response to previous epidemics will never be known. For the Great Plague was followed in the next year by the Great Fire: a conflagration fueled by the city's tightly packed and almost wholly wooden structures. London had experienced fires before. But that of 1666 was the worst, destroying a third of London and more than $80 \%$ of the core City where finance and trade were concentrated. Surprisingly few people died. But perhaps a quarter of the population that had survived the Great Plague of the year before was left homeless. Many people spent the following winter camped in tents in fields surrounding the city. Others fled the double devastation of plague and fire, never to return. London's prospects seemed bleak. An increasingly depressed Pepys wrote: "the City less and less likely to be built again, every body settling elsewhere, and nobody encouraged to trade." 25

\section{A Waste of Life: London's battle with disease in the 18th Century}

London struggled through the remainder of the $17^{\text {th }}$ and the first half of the $18^{\text {th }}$ Centuries with a slow, piecemeal reconstruction. Various grand plans for a new and orderly city came to nothing. The London that rose from the ashes had much the street plan of the old one. That London was, however, less flammable, as stone replaced wood as the preferred building material. In the city center, financed by a new coal tax, thoroughfares were paved and widened, drainage sewers were added, and several grand structures were built that still stand today, including Guildhall and numerous churches by Christopher Wren including St. Paul's Cathedral. Reflecting on the result one giddy resident heralded London as "not only the finest, but the most healthy city in the world." 26 
Beautiful it may have been, at least in the newly built center city if not the extensive outlying slums. But healthy it was not. In fact, London experienced a general rise in mortality throughout the $17^{\text {th }}$ Century and had by the second quarter of the $18^{\text {th }}$ Century become an unprecedentedly unhealthy place. ${ }^{27}$ More than a third of the babies born in the city died in infancy. Overall life expectancy was a mere 18 years, barely half of what it was then in England as a whole and less than a quarter of what it is today (see Figure 2).

Figure 2: Life expectancy at birth in London and England (years) ${ }^{28}$

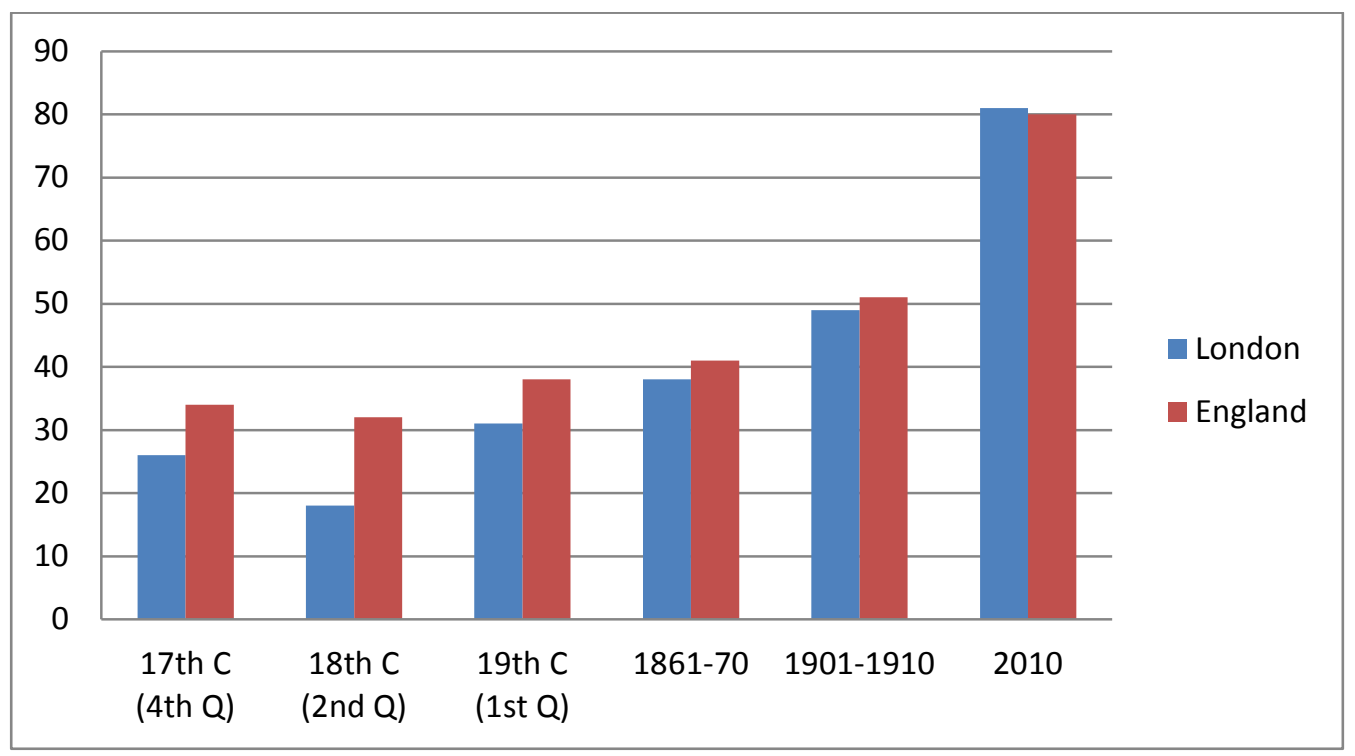

One historian summarized the consequences as follows:

For most of the eighteenth century London is dominated by a sense of the 'waste of life'....29

The causes of London's deteriorating health in the early $18^{\text {th }}$ Century were unknown at the time and remain difficult to disentangle today. It seems fairly certain, however, that no major new diseases arrived in London during this period. Neither long term trends in climate nor food shortages seem to have played a central role. More likely, the major contributor to the decline of health in London during this period was the growing density of people with little immunity to the many diseases that were endemic to the city. This trend had two, and possibly three, interacting components:

- First was the extraordinary flow of young immigrants from the countryside.

Perhaps three quarters of Londoners at the time had been born somewhere else, primarily in the rural areas of England, Scotland and Ireland. ${ }^{30}$ Most of these immigrants had experienced during their rural childhoods relatively few encounters with the microbes they would meet in London, and thus had neither been selected for, nor developed, immunity.

- Second was the dismal condition of London's housing stock. The stagnant economy had slowed new house construction to a trickle. As a result, existing buildings were 
subject to decay and "internal colonization": repeated subdivision into smaller and smaller rooms packed with more and more people, rats and lice.

- Third may well have been depressed rates of breast feeding. The extent of lowered breast feeding in this period is unclear but seems to have been substantial. Causes may have involved changes in demands of work, general illness, worsening nutrition or social customs. The consequences, however, were stark. Breast feeding provided infants who received it with food that was nutritious, free from contamination and laden with antibodies and other antimicrobial substances passed on from the mother. Children lacking these benefits due to limited or no breast feeding may have been 5-10 times more likely to die as infants than those exclusively raised on breast milk. ${ }^{31}$

Together, these three components - a flow of immunologically naïve immigrants, increased crowding in dilapidated housing, and a lack of breast feeding-created in London a perfect environment for efficient transmission of the many diseases endemic in the city. The "waste of life" that characterized the city in the $18^{\text {th }}$ Century was the result.

But if London of the early $18^{\text {th }}$ Century was a death trap, it was also the center of a generally prosperous England's central government, its greatest port, and its largest manufacturing center. Though London had deep and persistent problems, it was also growing a vibrant civic life. Coffee houses, newspapers and political debate proliferated. Business prospered. And social reformers began to address what they saw as the problems of the poor, providing workhouses to alleviate poverty, hospitals to support newborns and treat the sick, and generally striving to make the city a better place to live.

One of the most effective social reforms focused on smallpox. In terms of cumulative deaths, this was almost certainly London's single most lethal disease of the time. A fairly effective preventative treatment involving subcutaneous grafting of pustules or scabs from an infected individual had been known for centuries in other parts of the world with a longer history of smallpox. But how these "inoculation" or "variolation" treatments worked was not understood. They were therefore rejected as without merit by the scholars of the Royal Society and London's medical profession. Eventual adoption in London owed less to science than to the determined advocacy of Lady Mary Montague. As wife of England's ambassador to the Sublime Porte, Lady Montague had seen the effectiveness of variolation on her journeys. When her testimony did not change minds of establishment science, she had the treatment successfully applied to her own daughter in the presence of physicians of the royal court. Faced with this evidence, and a high demand for protection from smallpox, the medical establishment undertook in the early 1720s some systematic experimentation (on prisoners and orphans). The generally positive results of these morally questionable experiments finally led the experts to endorse the variolation procedure. The slow adoption of variolation in both London and the hinterlands from which its immigrants came helped, by 1760, to turn the tide against smallpox and to nudge along a slow decline in deaths attributed to it. ${ }^{32}$ Progress accelerated once true vaccination was added to the arsenal of anti-smallpox measures through the pioneering efforts of Edward Jenner in the early $19^{\text {th }}$ Century. ${ }^{33}$ The Royal Society rejected his initial paper on the subject, but he and a growing number of others who had been persuaded by the evidence persisted. 
By the middle of that century, the cumulative efforts of Montague, Jenner and other pragmatists - with only a little help from scientific theory-had relegated smallpox to a relatively minor role as a cause of death in London. ${ }^{34}$ Coupled with the departure of the plague (which had largely disappeared from London in the wake of the Great Fire), with the better nutrition and housing that came with a recovering economy and with continuing efforts of civic reformers and medical practitioners, the health of the city finally began to improve. A Londoner born in the 1820s had twice the chance of surviving infancy, and almost twice the life expectancy of one born a century earlier. ${ }^{35}$ With its demographic transition firmly underway, the city embarked on a century of rapid population growth. This would take it from about one million inhabitants in 1800 to more than six million people (supported by 300,000 horses) by 1900 .

\section{Water, Waste \& Sewers up to the Great Stink of 1858: Victorian London}

As a rapidly growing London took an increasingly dominant place on the world stage, the city's physical infrastructure and domestic governance arrangements lagged behind. London's chronic shortage of quality housing has already been noted and certainly worsened over this period. But nowhere was the stress of rapid urban growth clearer than in London's losing battles with its enduring challenges of managing its water and solid wastes. With the exception of the very wealthy, the million inhabitants of early $19^{\text {th }} \mathrm{C}$. London still relied for disposal of human excrement on essentially the same system of cesspits, night-soil men, hand-pumps and open sewers that had been developed to serve a medieval city of $1 / 40^{\text {th }}$ the size. ${ }^{36}$ For water supply, poorer districts continued to rely on the shallow wells that had served the city for centuries. Now, however, the growing demand for water was met by private companies intent on generating returns for their investors. They did so by encouraging higher and higher water consumption. But they could find no profit in handling the orderly disposal of the waters they provided, so sewage systems remained undeveloped.

The farms that once received most of the contents of the cesspits as manure were increasingly far removed from the city, making disposal of wastes there more costly and less likely to occur. (That recycling system would collapse almost entirely after 1847 when an expanding world trade system began to capitalize on Alexander von Humboldt's earlier discovery that huge Peruvian deposits of bird droppings, or guano, could be used as very effective agricultural fertilizer. Mined by indentured Chinese labor and shipped to England, guano killed the demand for London's night soil by farmers in its hinterland.) ${ }^{37}$ With no one motivated to remove its increasing quantity of wastes, London's disposal system was overwhelmed. Its cesspits overflowed into the other water management channels, comingling wastes with surface drainage water in the sewers, mixing it with many of the city's water sources and emitting an ever more pervasive stench.

Several responses to this deteriorating situation were possible. Unfortunately the responses initially adopted were guided by the prevailing science of the day, which was wrong. Confusing correlation with causation, scientists argued that disease was associated 
with air born "miasmas" arising from rotting fecal material and other wastes. This theory led to, or reinforced, a practical engineering emphasis on protecting people from tangible stenches rather than protecting water supplies from intangible contamination. In particular, it encouraged widespread adoption in the early $19^{\text {th }}$ Century of the new "water closet" technology that swept foul smelling human household waste away to "somewhere else." It supported the lifting (in 1803) of the long standing prohibition on connecting household drains directly to drainage sewers and thence to the "somewhere else" that was the Thames. It was eventually used to justify the requirement (in 1848) that such connections be made for all households in order to reduce dangerous back alley odors. The resulting success in flushing London's stenches away from houses meant that the Thames rapidly became a common cesspool for all of London, essentially replacing many of the thousands of backyard cesspools that had previously held the city's wastes. The miasma science of the day provided no reason to worry over the fact that this new Thames cesspool had somehow lost all of its once plentiful fish life and still served as the source of much of the city's drinking water.

Better knowledge, based on the germ theory of disease, would eventually show why dumping fecal matter into one's water supply had not just unaesthetic consequences but also unhealthy ones. But general acceptance of this healthier perspective on how to organize human activities would need to await the discoveries of Pasteur, Koch and their colleagues beginning in the 1860s. In the meantime, pressures to clean London of its centuries-old stenches persisted, driven by concerns over the continued presence of many old diseases in London and the arrival in England in 1831 of a deadly new one from Asia: cholera. Cholera was a terrifying disease, even for a city accustomed to epidemics. It would kill by dinner people who had seemed healthy at breakfast and struck down rich and poor alike. London's first epidemic surged through the city in 1832, killing more than 6000. Medical science was initially unable to offer alternatives to miasmic accounts of the disease's origins or propagation. Remedial treatments thus explored all sorts of ad hoc and ultimately ineffectual measures. And public health efforts continued to focus on separating people from the stench, rather than people from their feces.

Fortunately, some measures undertaken to improve the smell and other aesthetic qualities of London's disgusting drinking water coincidentally also reduced the risk of water-borne disease, including cholera. For example, some of the private water supply companies competing for Londoners' business developed sources from relatively sweet-smelling (but also disease free) tributaries and springs. Others introduced the innovation of slow percolation through sand for the purpose of removing waste from water before it could stink. But this filtering process accidentally and unknowingly also removed most bacteria before they could kill, which is why it remains widely used today. Such measures doubtless contributed to the reduction of both stench and disease in the early $19^{\text {th }}$ Century. But they were not widely enough adopted to spare London from a return of cholera in 1848/9 and $1853 / 4$, with each outbreak killing more than 10,000 people.

By the time of these mid-century outbreaks, however, what today we would recognize as the modern science of statistical inference had begun to take form. Drawing from the extensive records of the location and causes of deaths kept by the city, scientists were able 
to make empirical headway on the disease front, even under the burden of incorrect miasma theories regarding those diseases' origins and propagation. Most famously, the physician John Snow concluded from data he mobilized on deaths occurring during the $1848 / 1849$ cholera outbreak that the disease was more likely to result from an ingestion of a particle than from inhalation of miasmic air. Snow's statistical arguments did not immediately carry the day in scientific circles. But along with politically forceful arguments from the royal palace that the Thames water stank and tasted terrible, plus the persistent public fear of another cholera epidemic, his findings almost certainly helped gain passage of the Metropolis Water Act of 1852. The Act required that by 1855 all of London's drinking water taken from the Thames would have to be sourced from above the limits of its tidal reach (and so upstream of the city's pollution), and would have to be passed through the slow sand filters that up to then were only in patchy use.

The Act was too little, too late to spare London another cholera epidemic in 1853/4. But intense study of the mortality patterns exhibited in that epidemic by Snow and the scientists on London's Board of Health finally showed beyond reasonable scientific doubt that people who drank putrefied water during cholera outbreaks were much more likely to die than those who drank relatively pure water, even when they lived in common neighborhoods exposed to the same "miasmas" of air and other environmental conditions. In a scientifically admirable if practically exasperating show that they correctly understood the limits of epidemiological statistics, however, the scientists of the Health Board were careful to stress that they had not shown that bad water caused cholera and had no theory that would explain such causation.

They did, however, have compelling evidence of the greatest practical significance: substituting clean water for filthy water radically reduced the chances of contracting cholera and other diseases. They also presciently pointed out that while implementing the Water Act's requirement to use only the upper Thames as a source might help limit the immediate risk of cholera, it "remains but imperfect and precarious while ... (up-stream) populations exercise a right of sewerage into the drinking water of London." 38 Private water suppliers exploited the scientists' caution to press their claim that Thames water, though "nourishing a population of animalcules, would not be noxious to health." 39 Politicians dithered about the administrative and financial hurdles involved in establishing clean water supplies. John Snow famously demonstrated that removing the handle of the contaminated Broadstreet Pump could arrest the local spread of the 1853/4 cholera epidemic. But once that epidemic had passed little action followed from what we now know were the broadly correct and potentially useful scientific findings of the Health Board.

Action, when it did come, was precipitated not by scientific arguments but by cataclysmic events. In this case, a particularly hot June in 1858 transformed London's communal cesspool-the River Thames-from its chronic state of mere foulness into what would become notorious as the "Great Stink." A contemporary wrote, 
Such was the overpowering smell from the Thames, that the curtains of the Commons were soaked in chloride of lime in a vain attempt to protect the sensitivities [of the rich and powerful]. 40

The future prime minister of England, Benjamin Disraeli, was seen fleeing the Chamber, decrying the "Stygian pool" that was sloshing back and forth with the tides through the middle of what was supposed to be the greatest city on earth. When cooler weather allowed it to reconvene, Parliament acted with unprecedented speed. By summer's end it had authorized a massive and innovative program of sewer construction. Within seven years this huge infrastructure project would capture much of the household sewage of London and divert it to discharges downstream of the city. The reasons cited in the Parliamentary debates reflected not merely the unaesthetic qualities of the stink (which they had lived with, at one intensity or another, for all of their lives), but also what was now a mix of beliefs that by eliminating the "miasma" of foul air, or the putrid water, or both, they might also reduce the incidence of cholera and other diseases that threatened to kill them.

Subsequent events seemed to justify their hopes. Cholera returned to London for what proved to be the last time in 1866. But it claimed only half the victims of previous outbreaks, with deaths concentrated in the parts of the city not yet fully served by the new sewer system. Mortality in London from typhoid fever and diarrhea declined as well, even as cities without sewer systems experienced recurrent epidemics. Victorian England, already smug for many reasons, celebrated its new sewer system as "the most extensive and wonderful work of modern times." 41

A major and daring accomplishment it was and one that most certainly improved the quality of life in London. Much of its basic structure remains in place today. The engineering marvel that was London's sewers did not, however, solve the problem of water and waste disposal, but just pushed them away: downstream and into the future. (Later measures would push them further still, first barging the wastes collected at sewer outfalls to the ocean for dumping, today discharging it into the global atmosphere through incineration.) London's sewer innovations of the 1860s didn't solve its disease problem, either. (With a robust germ theory in hand we now know that the big assault on water borne diseases was already - if not altogether consciously - well underway with the passage of the 1852 Water Act and its provisions for clean water sourcing and filtering.) In fact, the most important innovations surrounding the Great Stink and its resolution may not have involved how to engineer health, but rather how to govern it.

Before the Stink, responsibility for the water supply and waste systems was distributed among hundreds of local authorities, each with its own locally attuned rules and technologies. This self-organized patchwork may have been adequate, even superior, when London was smaller. But as the city grew, what had been local strength became a regional weakness of turf fights and incompatible piping. Crucially, however, the various Acts surrounding the Stink consolidated the local authorities under a new Metropolitan Board of Works. The Board was given the authority and resources to impose solutions at scale that previous measures had lacked. Above all, in the wake of the Great Stink a system was 
developed that allowed the Board and various municipalities of the greater London region to raise revenue for their water works through borrowing backed by property taxes and water use levies. These governance innovations provided the foundation on which subsequent public works measures to manage social-environmental interactions were built over the coming decades. ${ }^{42}$ Together with continuing advances in the science and engineering of water supply and waste removal, they bequeathed modern London both better human health and a better Thames environment than anyone in the $19^{\text {th }}$ Century had ever imagined, with productive fisheries, occasional swim races and rarely a stench to its name.

\section{Persistent Air Pollution \& the Great Smog: London's 20th Century43}

Preoccupied with their challenges involving water, cholera and fecal matter, Londoners of the $19^{\text {th }}$ and early $20^{\text {th }}$ Centuries seem to have taken their lack of air quality for granted, referring to their city not entirely unaffectionately as "The Smoke." (This is sadly ironic, for we know today that the health impacts of urban air pollution-particularly the particulate matter that constituted the London smokes-are substantial.) Arthur Conan Doyle, for example, seems to have been describing rather than criticizing London when he dispatched Sherlock Holmes on chases through the "dense yellow fog" that he saw as characteristic of the city in the late $19^{\text {th }}$ Century. Those traveling to London from the country were less sanguine. So were social critics such as Charles Dickens. His Esther of Bleak House, for example, asked on her arrival in London several decades before Holmes roamed its streets "whether there was a great fire anywhere? For the streets were so full of dense brown smoke that scarcely anything was to be seen."

As noted earlier, fumes and smoke had always been part of London life (and death). The complaints of the $13^{\text {th }}$ Century were largely due to industrial use of coal, particularly in the production of lime. As coal was increasingly adopted not only by industry but as a domestic heating and cooking fuel in the late $16^{\text {th }}$ Century, Londoners had thrown themselves into the normal work of pollution control: making the bad stuff go somewhere else. In this case, the "somewhere else" was the air of London, as indoor air pollution was shifted outdoors through increasing use of low-rise household chimneys. ${ }^{44}$ Complaints began to build again, scientific studies were conducted, but not much changed. A century later, the invention of the steam engine resulted in a rapid increase in coal use throughout the city. Some regulations to limit emissions were put in place, but these were largely focused on a relatively few industrial installations. The idea that Londoners themselves, devoted as they were to their individual hearths and chimneys, were a big part of the overall air pollution problem got little traction at all. As a result, the same combination of a surge of London's population and an industrial revolution that had overwhelmed the city's ability to provide acceptably healthy water to its people in the $19^{\text {th }}$ Century overtook its ability to provide acceptably healthy air in the $20^{\text {th }}$.

A series of increasingly severe "pea soup" fogs in the first decades of the 20 $0^{\text {th }}$ Century brought about increasing concerns for the impact of deteriorating air quality on the city, its 
commerce and its inhabitants' health. The Second World War, however, turned peoples' attentions to more immediate concerns. The War affected London in multiple ways, as it did England and the world. Most immediate for the city, however, was the Blitz: the strategic bombing of the city by Germany in 1940. At least 20,000 Londoners were killed, a second "great fire" ravaged the city, and more than 300,000 of its houses together with much of its industrial base were destroyed. Many people fled the city, and the population continued to fall over the next half century.

But London once again showed itself able to recover and rebuild in the wake of disaster, once again drawing on people and other resources from a nation and foreign friends for which London had become simply indispensable. This rebuilding began to grapple seriously with housing and green space issues, and once again air pollution returned as a subject of discussion. Then, in December 1952, London experienced a week-long "killer smog" that was as (or more) severe than anything in today's headlines about rapidly growing cities of the developing world. Contemporary accounts refer to

the worst fog that I'd ever encountered. It had a ... strong, strong smell ... of sulfur... Even in daylight, it was a ghastly yellow color... You literally could not see your hand in front of your face. 45

Transportation stopped. A performance of La Traviata was cancelled because of poor visibility inside the opera hall. The black smoke permeated everything, from the stacks of the British Library to the underwear of householders. ${ }^{46}$ This single pollution episode came to be known as "the Great Smog" and may have killed as many as 12,000 Londoners ${ }^{47}-$ more than half the number killed by the entire wartime bombing blitz and comparable in numbers (though not proportions) to the toll of individual plague and cholera outbreaks of earlier times.

Unfortunately, the magnitude of the death toll was not fully appreciated for another 50 years when careful scholarship finally disentangled how this acute episode of air pollution increased the death rates from chronic respiratory conditions. Action therefore did not follow the Great Smog of 1952 as quickly or forcefully as it had the Great Stink of 1858. But in the wake of the Smog, air pollution would never again be accepted as an inevitable condition of living in London, and regulations to reduce it finally were accorded broad public support. Parliament eventually passed a Clean Air Act in 1956. This included for the first time efforts to control domestic as well as industrial production of smoke. It established "smokeless" zones, thus inducing fuel switches away from the dirtiest coals and effectively reducing particulate emissions. It did not address directly sulfur or other emissions, though some of these declined as well as a result of the smoke-driven fuel switches. Systematic progress on dealing with these other pollutants did not occur until the last decades of the $20^{\text {th }}$ Century. Some of that progress was simply due to the continuing clearance and replacement of London's old housing and to the export of much of its manufacturing industry to other parts of the world. But efforts to improve London's air quality, like similar efforts elsewhere, benefited greatly from novel synergies that began to take shape in the 1980s between programs of transnational environmental research and programs of transnational environmental governance. For the first time, those programs 
systematically brought science to bear on the shortcomings of development strategies that dealt with wastes by pushing them elsewhere. Work on acid rain (involving many of the same pollutants as a The Great Smog) led the way, followed quickly by international programs integrating monitoring, research and governance to address the challenges of stratospheric ozone depletion, climate change and a still expanding array of other pollutants. ${ }^{48}$ These global scientific programs combined with regional initiatives by the European Union began to pull Britain toward more aggressive policies of environmental protection. They simultaneously provided leverage for local London reformers who succeeded in pushing forward home grown innovations such as the inner city congestion charge on automobile traffic.

Whether such coalitions of global science and local action in the environmental sphere can be expanded, or learned from, to provide comparable support for understanding and addressing the social dimensions of sustainability remains to be seen. What is clear is that today's urban centers are the crucibles in which some of the most integrated pursuits of sustainability are taking place. One of the most inventive such crucibles is, as it has been for centuries, the City of London.

\section{Sustainable development questions arising from the London case}

1. It has been said that cities in search of a sustainable future have always faced two central challenges: i) assuring a supply of materials and energy essential to their functioning while disposing effectively of the resulting wastes, and ii) developing a capacity to cope with shocks and stress. How does the history of London reflect on these challenges, and the ways of meeting them?

2. London's population has grown almost a thousand fold over the last millennium. Much of that growth has come in spurts -- one centered on about 1200 , one on about 1600 and the most recent on about 1850 - followed by periods of much slower growth or even decline (see Fig. 1). What does this pattern suggest about the role played by population growth in sustainable development?

3. London and other cities for much of their histories created environments that degraded human health, and thus human well-being, far more than did the environments of the surrounding countryside. And yet people kept immigrating to the London death trap. Why? What are the implications for thinking about sustainable development in a globally mobile world?

4. London suffered major setbacks several times over the last millennium, whether by "Great Plagues," "Great Fires," "Great Stinks," "Great Wars” or "Great Smokes.” What should good assessments of the "sustainable development" of London have concluded about London's long term prospects just before, and just after, each of these destructive events? 
5. Which of the assets that form the "productive base" of a society were in fact damaged or degraded in each of the destructive episodes noted above? Which were conserved or enhanced? What does this suggest about the way that multiple assets ought to be handled in contemporary assessments of sustainability?

6. What does the history of London suggest about contemporary efforts to frame the challenge of sustainable development in terms of "a transition toward sustainability"?

7. Where in London's history are the greatest missed opportunities to set the city on a trajectory to more sustainable development? Where are the greatest seized opportunities? What do these answers suggest about general strategies to promote sustainability?

8. Technological innovation and scientific discovery played substantial roles in shaping the coevolution of society and environment in London. But technological solutions to one problem often became the technological causes of another problem. And science was often wrong, suggesting responses to sustainability concerns that proved to be ineffectual or counterproductive. How does the London experience suggest that we should treat science and technology in the design of future assessments and strategies to promote sustainability?

9. With all its continuing problems of housing, air quality, and social cohesion, London today is healthier and richer than it has ever been. More so than most places in the world, you can drink its water, breath its air, eat its food, imbibe its culture, and use it to shape a better world for yourself and your children. At least if you are rich enough. Given the multiple catastrophes and failures that have befallen London in the past, what should its present condition, and how it got there, teach us about the prospects for pursuing sustainability in London and the rest of the world?

\section{References Cited}

Baker, A., Findlay, G., Murage, P., Pettitt, G., Leeser, R., Goldblatt, P., et al. (2011). Fair London, Healthy Londoners. London: London Health Commission.

BBC. (1952). London fog clears after days of chaos. Retrieved Aug. 10, 2014, from http://news.bbc.co.uk/onthisday/hi/dates/stories/december/9/newsid 4506000/45 06390.stm.

BBC. (2002). Days of toxic darkness: Interview with Barbara Fewster. Retrieved Aug. 10, 2014, from http://news.bbc.co.uk/2/hi/uk news/2542315.stm.

Beier, A. L., \& Finlay, R. (1986). London 1500-1700: The Making of the Metropolis. London / New York: Longman.

Bell, M. L., \& Davis, D. L. (2001). Reassessment of the lethal London fog of 1952: Novel indicators of acute and chronic consequences of acute exposure to air pollution. Environmental Health Perspectives Supplements 109:389-394. 
Brimblecombe, P. (1987). The Big Smoke: A History of Air Pollution in London since Medieval Times. London / New York: Methuen.

Butzer, K. W., \& Endfield, G. H. (2012). Critical perspectives on historical collapse. Proceedings of the National Academy of Sciences 109:3628-3631.

Daunton, M. (2004). London's "Great Stink" and Victorian urban planning. Retrieved 6/21, 2014, from

http://www.bbc.co.uk/history/trail/victorian britain/social conditions/victorian urb an planning 01.shtml.

Davenport, R., Schwarz, L., \& Boulton, J. (2011). The decline of adult smallpox in eighteenthcentury London. Economic History Review 64 (4): 1289-1314.

Economist Intelligence Unit. (2012). The Green City Index. Munich, Germany: Siemens.

Fildes, V. A. (1995). The culture and biology of breastfeeding: An historical review of Western Europe. In P. Stuart-Macadam \& K. A. Dettwyler (Eds.), Breastfeeding: Biocultural Perspectives (pp. 101-126). New York: Walter de Gruyter, Inc.

Finlay, R. (1981). Population and Metropolis: The Demography of London, 1580-1650. Cambridge / New York: Cambridge University Press.

Florida, R. L., Mellander, C., \& Gulden, T. (2012). Global metropolis: Assessing economic activity in urban centers based on nighttime satellite images. Professional Geographer 64 (2): 178-187.

Galloway, J. A., \& Potts, J. S. (2007). Marine flooding in the Thames Estuary and tidal river c.1250-1450: Impact and response. Area 39 (3): 370-379.

GB Historical GIS / University of Portsmouth, London GovOf through time | Population Statistics. (2009). A vision of Britain through time: Total population (London). Retrieved Aug. 10, 2014, from http://www.visionofbritain.org.uk/unit/10097836/cube/TOT POP.

George, M. D. (1965). London Life in the Eighteenth Century. New York: Harper \& Row.

Glacken, C. J. (1967). Traces on the Rhodian Shore: Nature and Culture in Western Thought from Ancient Times to the End of the Eighteenth Century. Berkeley, CA: University of California Press.

Greater London Authority. (2011). The London Plan: spatial development strategy for greater London July 2011. (Context and Strategy, ch. 1, para. 1.52). London: Greater London Authority.

Greater London Authority Demography Team. (2010). Infant Mortality: 2002-2008 (Update No. 09-2010). London: Greater London Authority.

Green, C. H. (2010). Case study brief-Sustainable urban water management in London. (Input to deliverable 6.1.5-6 Comparative Analysis of Enabling Factors for Sustainable Urban Water Management) Switch Project.

Halliday, S. (1999). The Great Stink of London: Sir Joseph Bazalgette and the Cleansing of the Victorian Capital. Thrupp, Stroud, Gloucestershire: Sutton Pub.

Harris, B. (2004). Public health, nutrition, and the decline of mortality: The McKeown thesis revisited. Social History of Medicine 17 (3): 379-407.

Huck, P. (1997). Shifts in the seasonality of infant deaths in nine English towns during the 19th century: A case for reduced breast feeding? Explorations in Economic History 34 (3): 368-386.

IESE Center for Globalization and Strategy. (2014). Cities in Motion Index 2014. University of Navarra, Spain: IESE Business School. 
Jackson, K. M., \& Nazar, A. M. (2006). Breastfeeding, the immune response, and long-term health. JAOA: Journal of the American Osteopathic Association 106 (4): 203-207.

Jenner, M. S. R. (1991). Early Modern English Conceptions of 'Cleanliness' and 'Dirt' as Reflected in the Environmental Regulation of London, c. 1530-c. 1700. (Ph.D. diss., Oxford University).

Keene, D. (2000). London from the post-Roman period to 1300. In D. M. Palliser (Ed.), The Cambridge Urban History of Britain (pp. 187-216). Cambridge: Cambridge University Press.

Keene, D. (2012). Medieval London and its supply hinterlands. Regional Environmental Change 12 (2): 263-281.

King, S. (1997). Dying with style: Infant death and its context in a rural industrial township 1650-1830. Social History of Medicine 10 (1): 3-24.

Knodel, J., \& Kinter, H. (1977). Impact of breast feeding patterns on biometric analysis of infant-mortality. Demography 14 (4): 391-409.

Landers, J. (1993). Death and the Metropolis: Studies in the Demographic History of London, 1670-1830. Cambridge / New York: Cambridge University Press.

Lansing, J. S. (2006). Perfect Order: Recognizing Complexity in Bali. Princeton, NJ: Princeton University Press

Levin, S. A., \& Clark, W. C. (2010). Toward a Science of Sustainability: Report from a Conference. Princeton, NJ: Princeton Environmental Institute. http://dash.harvard.edu/handle/1/9774654.

Levin, Simon, Xepapadeas, Tasos, Crepin, Anne-Sophie, et al. (2013). Social-ecological systems as complex adaptive systems: Modeling and policy implications. Environment and Development Economics 18:111-132.

Liu, J., Mooney, H., Hull, V., Davis, S. J., Gaskell, J., Hertel, T., et al. (2015). Systems integration for global sustainability. Science 347 (6225). [doi:10.1126/science.1258832]

McNeill, J. R. (2010). The state of the field of environmental history. Annual Review of Environment \& Resources 35:345-374.

Moon, B. K. (2012). Our struggle for global sustainability will be won or lost in cities (Speech to High-level delegation of mayors and regional authorities), April 23, 2012 (Press release No. SG/SM/14249 ENV/DEV/1276 HAB/217). New York: United Nations.

Museum of London. (2005). London's burning: The Great Fire of London 1666. Retrieved Aug. 9, 2014, from http://archive.museumoflondon.org.uk/Londons-Burning/.

Musuem of London. (2011). London plagues, 1348-1665. Retrieved Aug. 9, 2014, from http://www.museumoflondon.org.uk/explore-online/pocket-histories/londonplagues-13481665/black-death-13481350/.

PwC. (2014). Cities of Opportunity 6. Delaware, USA: PricewaterhouseCoopers.

Razzell, P. E. (2003). The Conquest of Smallpox: The Impact of Inoculation on Smallpox Mortality in Eighteenth Century Britain (2nd ed.). Firle: Caliban Books.

Razzell, P. E. (2011). The decline of adult smallpox in eighteenth-century London: A commentary. Economic History Review 64 (4): 1315-1335.

Riedel, S. (2005). Edward Jenner and the history of smallpox and vaccination. Proceedings Baylor University Medical Center 18 (1): 21-25.

Simon, J. (1856). Report of the Last Two Cholera-epidemics of London, as Affect by the Consumption of Impure Water. London, England: General Board of Health. 
Social Learning Group. (2001). Learning to Manage Global Environmental Risks. Vol. 1, A Comparative History of Social Responses to Climate Change, Ozone Depletion, and Acid Rain. Cambridge, MA: MIT Press.

Stuart-Macadam, P., \& Dettwyler, K. A. (1995). Breastfeeding: Biocultural Perspectives. New York: Aldine De Gruyter.

Tebrake, W. H. (1975). Air-pollution and fuel crises in preindustrial London, 1250-1650. Technology and Culture 16 (3): 337-359.

Turner, B. L., \& Sabloff, J. A. (2012). Classic period collapse of the central Maya lowlands: Insights about human-environment relationships for sustainability. Proceedings of the National Academy of Sciences 109:13908-13914.

Twigg, G. (1993). Plague in London: spatial and temporal aspects of mortality. In J. A. I. Champion (Ed.), Epidemic Disease in London (Center for Metropolitan History Working Paper Series No. 1) (pp. 1-17). London: Center for Metropolitan History. Retrieved from http://events.sas.ac.uk/support-research/publications/923.

UN Population Division. (2012). World Urbanization Prospects, the 2011 Revision: Highlights No. ESA/WP/224). New York: UN Department of Economic and Social Affairs, Population Division.

UNFPA (United Nations Population Fund). (2007). Urbanization: A majority in cities. Retrieved August 9, 2014, from http://www.unfpa.org/pds/urbanization.htm.

Wohl, A. S. (1983). Endangered Lives: Public Health in Victorian Britain. London: J. M. Dent.

Woods, R. (2000). The Demography of Victorian England and Wales. Cambridge / New York: Cambridge University Press.

Wrigley, E. A., \& Schofield, R. (1989). The Population History of England, 1541-1871: A Reconstruction. Cambridge / New York: Cambridge University Press.

\section{Endnotes}

${ }^{1}$ Liu, J., Mooney, H., Hull, V., Davis, S. J., Gaskell, J., Hertel, T., et al. 2015. Systems integration for global sustainability. Science 347(6225). [doi:10.1126/science.1258832]; Levin, Simon, Xepapadeas, Tasos, Crepin, Anne-Sophie, et al. 2013. Social-ecological systems as complex adaptive systems: Modeling and policy implications. Environment and Development Economics. 18:111-132.

${ }^{2}$ The scarcity of accessible empirical accounts of long term dynamics of socialenvironmental systems was one conclusion of a workshop on the future of sustainability science recently hosted by the US National Science Foundation (Levin, S. A., \& Clark, W. C. 2010. Toward a Science of Sustainability: Report from a Conference. Princeton, NJ: Princeton Environmental Institute. http://dash.harvard.edu/handle/1/9774654). That said, the field of environmental history provides a growing number of potentially relevant cases (e.g., McNeill, J. R. 2010. The state of the field of environmental history. Annual Review of Environment \& Resources 35:345-374), as does geography (e.g., Butzer, K. W., \& Endfield, G. H. 2012. Critical perspectives on historical collapse. Proceedings of the National Academy of Sciences 109: 3628-3631; Turner, B. L., \& Sabloff, J. A. 2012. Classic period collapse of the central Maya lowlands: Insights about human-environment relationships for 
sustainability. Proceedings of the National Academy of Sciences 109: 13908-13914) and anthropology (e.g., Lansing, J. S. 2006. Perfect Order: Recognizing Complexity in Bali. Princeton, NJ: Princeton University Press). In addition, systematic long term studies of ongoing social-environmental systems at particular sites have been launched as part of the LTER network and are producing provocative results (e.g., The Baltimore Ecosystem Study, http://www.beslter.org/ and the Central Arizona-Phoenix Study, http://caplter.asu.edu/). ${ }^{3}$ Florida, R. L., Mellander, C., \& Gulden, T. (2012). Global metropolis: Assessing economic activity in urban centers based on nighttime satellite images. Professional Geographer 64 (2): 178-187.

${ }^{4}$ UN Population Division (2012). World Urbanization Prospects, the 2011 Revision: Highlights. ESA/WP/224. New York: UN Department of Economic and Social Affairs, Population Division.

5 UNFPA (United Nations Population Fund). (2007). Urbanization: A majority in cities. Retrieved August 9, 2014, from http://www.unfpa.org/pds/urbanization.htm.

${ }^{6}$ Moon, B. K. (2012). Our struggle for global sustainability will be won or lost in cities (Speech to High-level delegation of mayors and regional authorities), April 23, 2012 (Press release No. SG/SM/14249 ENV/DEV/1276 HAB/217). New York: United Nations. Moon's phrasing here links back to that of Maurice Strong, secretary general of the first UN Earth Summit in Rio de Janeiro, who said words to the effect of "if our planet is to remain a hospitable and sustainable home for the human species, the battle would be won or lost in major urban areas."

7 IESE Center for Globalization and Strategy. (2014). Cities in Motion Index 2014. University of Navarra, Spain: IESE Business School; PwC. (2014). Cities of opportunity 6. Delaware, USA: PricewaterhouseCoopers; Economist Intelligence Unit. (2012). The Green City Index. Munich, Germany: Siemens.

8 Greater London Authority. (2011). The London Plan: Spatial development strategy for greater London July 2011. Context and Strategy (ch. 1, para. 1.52). London: Greater London Authority.

${ }^{9}$ Brimblecombe, P., (1987). The Big Smoke: A History of Air Pollution in London since Medieval Times. London, New York: Methuen, p. 68. The author also notes that London's situation had none of the inversion-prone basin attributes that would eventually so plague the air pollution control efforts of other cities, e.g., Los Angeles.

${ }^{10}$ Glacken, C. J. (1967). Traces on the Rhodian Shore: Nature and Culture in Western Thought from Ancient Times to the End of the Eighteenth Century. Berkeley, CA: University of California Press, p. 336.

11 This section draws extensively on the following accounts:

For water, Halliday, S. (1999). The Great Stink of London: Sir Joseph Bazalgette and the Cleansing of the Victorian Capital. Thrupp, Stroud, Gloucestershire: Sutton; and Green, C. H. (2010). Case study brief - Sustainable urban water management in London. (Input to deliverable 6.1.5-6 Comparative Analysis of Enabling Factors for Sustainable Urban Water Management) Switch Project.

For forest, coal, and air quality connections, Tebrake, W. H. (1975). Air-pollution and fuel crises in preindustrial London, 1250-1650. Technology and Culture 16 (3): 337-359. 12 Sources: 1801-present is from GB Historical GIS / University of Portsmouth, London GovOf through time | Population Statistics | A vision of Britain through time: Total 
population. http://www.visionofbritain.org.uk/unit/10097836/cube/TOT POP); 17001800 is from Landers, J., (1993). Death and the Metropolis: Studies in the Demographic History of London, 1670-1830. Cambridge / New York: Cambridge University Press; Data for earlier period are from Derek Keene. (2000). London from the post-Roman period to 1300. In D. M. Palliser (Ed.), The Cambridge Urban History of Britain (pp. 187-216).

Cambridge: Cambridge University Press; Keene, D. (2012). Medieval London and its supply hinterlands. Regional Environmental Change 12 (2): 263-281.

13 Halliday, S. (1999). Op. cit., pg.44, quoting HT Riley, ed. Memorials of London Life, pg. 295. Metropolitan Archives.

14 Tebrake, W. H. (1975). Op. cit., citing Duby, G. (1971). Medieval agriculture 900-1500. In C. M. Cipolla (Ed.), The Fontana Economic History of Europe. London: Collins. p. 199.

15 Tebrake, W. H. (1975). Op. cit., citing Calendar of Close Rolls, Edward I (1302-7), p. 537.

16 Information on the plague in London is from: Museum of London. (2011). London plagues 1348-1665. Retrieved Aug. 9, 2014, from http://www.museumoflondon.org.uk/exploreonline/pocket-histories/london-plagues-13481665/black-death-13481350/.

17 Galloway, J. A., \& Potts, J. S. (2007). Marine flooding in the Thames Estuary and tidal river c.1250-1450: impact and response. Area 39 (3): 370-379.

18 Tebrake, W. H. (1975). Op. cit., citing Calendar of Close Rolls, Edward I (1302-7), p. 537. 1923 Henry VIII Cap. V.; Jenner has shown that refuse disposal in $16^{\text {th }}$ and $17^{\text {th }}$ Century London was generally well organized with officials requiring streets swept 2x per day, at least in central London (Jenner, M. S. R., Early Modern English Conceptions of 'Cleanliness' and 'Dirt' as Reflected in the Environmental Regulation of London, c. 1530-c. 1700 [Ph.D. diss., Oxford University, 1991], especially chapter 2.)

${ }^{20}$ Brimblecombe, P. (1987). Op. cit., pp. $67 \mathrm{ff}$, citing the work of 17 th C. scientists Margaret Cavendish, Kenelm Digby, and John Evelyn.

${ }^{21}$ Halliday, S. (1999). Op. cit., pg. 47 quoting Analytical Index to the Rememgrencia, 15791664 (Corporation of London, 1878), p. 482. Guildhall Library.

${ }^{22}$ Malnutrition was endemic in London, especially for the poor. (Hard data are not available until later periods. But poor children born in London in the mid-18 ${ }^{\text {th }}$ Century would grow up to be a full 10" shorter than their contemporaries in rural England or than children born in London two centuries later. That said, there is little convincing evidence that changes in nutritional status were associated with major disease outbreaks. See: Landers, J. (1993). Op. cit. Pp.66-68.

23 Twigg, G. (1993). Plague in London: spatial and temporal aspects of mortality. In J. A. I. Champion (Ed.), Epidemic Disease in London (Center for Metropolitan History Working Paper Series No. 1) (pp. 1-17). London: Center for Metropolitan History. Retrieved from http://events.sas.ac.uk/support-research/publications/923.

24 Information on the Great Plague, including the quote from Pepys, is from:

Museum of London. (2011). Op. cit.

25 The account of the Great Fire and its consequences is from: Museum of London. (2005).

London's burning: The Great Fire of London 1666. Retrieved Aug. 9, 2014, from http://archive.museumoflondon.org.uk/Londons-Burning/.

26 Ibid.

27 Finlay, R. (1981). Population and Metropolis: The Demography of London, 1580-1650. Cambridge, New York: Cambridge University Press. 
28 Pre-1850 London data are from: Landers, J., (1993). Op. cit., Fig. 5.3 and Table 4.10. Contemporary London data are from Public Health England database (http://www.lho.org.uk/), esp. Baker, A., Findlay, G., Murage, P., Pettitt, G., Leeser, R., Goldblatt, P., et al. (2011). Fair London, Healthy Londoners. London Health Commission; and Greater London Authority Demography Team. (2010). Infant mortality: 2002-2008 Update 09-2010). London: Greater London Authority. Pre-1850 England data are from Wrigley, E. A., \& Schofield, R. (1989). The Population History of England, 1541-1871: A Reconstruction. Cambridge, New York: Cambridge University Press (Tables 7.15 [life expectancy at birth, by quartiles] and 7.19 [infant mortality, by half century]). Data for London and England 1850-1910 are from Woods, R. (2000). The Demography of Victorian England and Wales. Cambridge / New York: Cambridge University Press.

${ }^{29}$ George, M. D. (1965). London Life in the Eighteenth Century. New York, Harper \& Row 1965, pp. 35-6.

30 Landers, J. (1993). Op. cit. p. 47.

${ }^{31} \mathrm{~A}$ thorough case for the role of breast feeding in the high mortality rates of $18^{\text {th }} \mathrm{C}$. London is made in: Landers, J., (1993). Op. cit. p. 47. Further insights into the data behind this case are given by: Fildes, V. A. (1995). The culture and biology of breastfeeding: An historical review of Western Europe. In P. Stuart-Macadam \& K. A. Dettwyler (Eds.), Breastfeeding: Biocultural Perspectives (pp. 101-126). New York: Walter de Gruyter, Inc.; King, S. (1997). Dying with style: Infant death and its context in a rural industrial township 1650-1830. Social History of Medicine 10(1): 3-24; and Knodel, J., \& Kinter, H. (1977). Impact of breast feeding patterns on biometric analysis of infant-mortality. Demography 14 (4): 391-409. The assertion that breast feeding can increase infant survival chances 5-10 fold is from a study by Huck (1997; Table 4) of the generally more sanitary and less disease infested London of 1908-1918, and thus almost certainly represents a lower limit (Huck, P. (1997). Shifts in the seasonality of infant deaths in nine English towns during the 19th century: A case for reduced breast feeding? Explorations in Economic History 34 (3): 368-386). An accessible summary of the benefits of breastfeeding is provided by: Jackson, K. M., \& Nazar, A. M. (2006). Breastfeeding, the immune response, and long-term health. JAOA: Journal of the American Osteopathic Association 106 (4): 203-207.

32 The progress is most evident in the wealthy, who adopted variolation early. For England as a whole, until the middle of the $18^{\text {th }}$ Century life expectancy of ducal families was indistinguishable from that of commoners, averaging 30-35 years. After that, being rich began to matter: by 1866/71, a child born into a ducal family could expect to live 60 years, half again as long as the average Englander. See: Harris, B. (2004). Public health, nutrition, and the decline of mortality: The McKeown thesis revisited. Social History of Medicine 17 (3): 379-407.

33 The term "vaccination" was introduced by scientist Edward Jenner to describe his demonstration in 1796 that by exposing a person to cowpox-a relatively mild disease commonly experienced by milkmaids-he could protect them from subsequent infections by smallpox. Jenner's paper reporting the evidence for his new approach was rejected by the Royal Society. He nevertheless persisted, privately published a report on his findings, and distributed the vaccine freely to all who were willing to try it for themselves or to treat others. Despite much controversy-part of it arising from campaigns in support of the now well-established but less effective variolation procedure-he and his followers achieved 
results. By the early $19^{\text {th }}$ Century widespread acceptance of vaccination brought about rapid declines in smallpox deaths.

34 Principal sources for this smallpox story are Razzell, P. E. (2003). The Conquest of Smallpox: The Impact of Inoculation on Smallpox Mortality in Eighteenth Century Britain (2nd ed.). Firle: Caliban Books; and Riedel, S. (2005). Edward Jenner and the history of smallpox and vaccination. Proceedings Baylor University Medical Center 18 (1): 21-25. Useful additional perspectives drawing on newer data are provided in: Davenport, R., Schwarz, L., \& Boulton, J. (2011). The decline of adult smallpox in eighteenth-century London. Economic History Review 64 (4): 1289-1314; and: Razzell, P. E. (2011). The decline of adult smallpox in eighteenth-century London: a commentary. Economic History Review 64 (4): 1315-1335.

35 Landers, J., (1993). Op. cit.

36 This section draws heavily on Green, C. H. (2010). Op. cit. and Halliday, S. (1999). Op. cit.

37 Halliday, S. (1999). Op. cit., pp. 52ff.

38 Simon, J. (1856). Report of the Last Two Cholera-epidemics of London, as Affect by the Consumption of Impure Water. London, England: General Board of Health, pg. 12.

39 Ibid., pg. 10.

40 Daunton, M. (2004). London's “Great Stink" and Victorian urban planning. Retrieved 6/21, 2014, from http://www.bbc.co.uk/history/trail/victorian britain/social conditions/ victorian urban planning 01.shtml.

41 Halliday, S. (1999). Op. cit., pg. 107.

42 The innovation arguments advanced here are drawn from Green, C. H. (2010). Op. cit.

43 Brimblecombe, P. (1987). Op. cit.

44 It is worth noting, in light of the present debates around indoor cook stoves in the developing world, that according to Brimblecombe (1987, Op. cit., p. 55), one observer in the early $17^{\text {th }}$ Century wrote "that the number of chimneys had increased greatly since his youth (mid-16 ${ }^{\text {th }}$ Century). In those times, he wrote, smoke indoors had been regarded as "hardening the timbers of the house and as a disinfectant to ward off disease."

45 BBC. (2002). Days of toxic darkness: Interview with Barbara Fewster. Retrieved Aug. 10, 2014, from http://news.bbc.co.uk/2/hi/uk news/2542315.stm.

46 BBC. (1952). London fog clears after days of chaos. Retrieved Aug. 10, 2014, from http://news.bbc.co.uk/onthisday/hi/dates/stories/december/9/newsid 4506000/45063

90.stm.

47 Bell, M. L., \& Davis, D. L. (2001). Reassessment of the lethal London fog of 1952: Novel indicators of acute and chronic consequences of acute exposure to air pollution.

Environmental Health Perspectives Supplements 109:389-394.

48 Social Learning Group. (2001). Learning to Manage Global Environmental Risks. Vol. 1, A Comparative History of Social Responses to Climate Change, Ozone Depletion, and Acid Rain. Cambridge, MA: MIT Press. 